\title{
Simulation Analysis of the Effects of a Rail Vehicle Running with Wheel Flat
}

\author{
Ján Dižo ${ }^{1}$, Stasys Steišūnas ${ }^{2}$, Miroslav Blatnický ${ }^{1}$ \\ ${ }^{1}$ Faculty of Mechanical Engineering, University of Žilina, 01026 Žilina. Slovak Republic. E-mail: \\ jan.dizo@fstroj.uniza.sk, miroslav.blatnicky@fstroj.uniza.sk \\ ${ }^{2}$ Faculty of Transport Engineering, Vilnius Gediminas Technical University, LT-03224 Vilnius. Lithuania. E-mail: sta- \\ sys.steisunas@vgtu.lt
}

This contribution deals with the computer simulation and the follow analysis of the rail vehicle running with wheel flat. It comprises of two parts. The first part addresses to the problem of rail vehicle operational, which wheel is damaged. There are several types of wheel damages. In this work the wheel flat problem is introduced. Generally, the rail vehicle running with wheel flat is adverse because the track can be shopworn, some parts of rail vehicle can be damaged and also operational condition for passenger or goods (depending on kind of rail vehicle) can be worse markedly. There is also included a system of forces and accelerations measurement during rail vehicle running on the given track section. The second part includes computer modelling and simulation of this phenomenon. Analyses were focused on the assessemnt of the rail vehicle motion smoothness and its damaging impact on the track. For this, there was created computer model of a twin-bogies passenger car, which the one wheel was modelled as damaged, i.e. wheel flat. Then, there were performed simulations of the rail vehicle running at various speeds. The passenger car was run on the straight track without irregularities in order to avoid adding excitation. Subsequently, values of the vertical wheel forces of the wheel with flat was evaluated.

Keywords: Dynamic analysis, Computer simulation, Rail vehicle, Wheel flat

\section{Acknowledgement}

This paper was created during the processing of the project "RAILBCOT - RAIL Vehicles Brake COmponents Test Stand”, ITMS Code 26220220011 based on the support of Research and Development Operational Program financed by European Fund of a Regional Development. The work was also supported by the project No. APVV-0842-11: “Equivalent railway operation load simulator on the roller rig".

References

[1] DIŽO, J., STEIŠŪNAS, S., BLATNICKÝ, M. (2015). Dynamic analysis of motion smoothenss of rail vehicle with wheel-flat. In: $22^{\text {nd }}$ International Conference „Current Problems in Rail Vheicles - PRORAIL 2015 “: Proceedings, Žilina, September 16 -18, 2015, Slovak Republic, Žilina: Scientific and Technical Society at the University of Žilina, 2015, Pp. 84-92, ISBN 978-80-89276-48-6.

[2] GALLIKOVÁ, J., POPROCKÝ, R. (2015). Maintenance according to the technical state with use of the enterprise asset management systems. In: Zeszyty naukowe Instytutu Pojazdów: mechanika, ekologia, bezpieczeństwo, mechatronika, 3 (103)/(2015), Pp. 67-75, ISSN 1642-347X.

[3] GALLIKOVÁ, J., POPROCKÝ, R. (2015). Risks assessment in rail vehicles (In Slovak). In: 22 ${ }^{\text {nd }}$ International Conference „Current Problems in Rail Vheicles - PRORAIL 2015 “: Proceedings, Žilina, September 16 -18, 2015, Slovak Republic, Žilina: Scientific and Technical Society at the University of Žilina, 2015, Pp. 151-158, ISBN 978-80-89276-48-6.

[4] GERLICI, J., LACK, T., HARUŠINEC, J. (2014). The test stand load modulus implementation for the realistic railway operation in the laboratory conditions. In: Manufacturing Technology: journal for science, research and production. Vol. 13, No. 4, Pp. 444-449, ISSN 1213-2489.

[5] GERLICI, J., ŠŤASTNIAK, P., LACK, T., HARUŠINEC, J. (2015a). Design of long freight railway wagon with variable use of loading space. In: Dynamical problems in rail vehicles 2015: Polish - Slovak scientific workshop: Warsaw 2015. - Warsaw: Warsaw University of technology, 2015, Pp. 6-13, ISBN 978-83-7814-367-3.

[6] GERLICI, J., LACK, T., HARUŠINEC, J. (2015b). Loading collectives for experimental research on the test stand RAILBCOT specification. (In Slovak) In: $22^{\text {nd }}$ international conference ,current problems in rail vehicles PRORAIL 2015“, September 16 - 18 2015, Žilina, Slovakia, Vol. 1, Pp. 171-182, ISBN 978-80-89276-48-6.

[7] HAUSER, V., ŠŤASTNIAK, P., GERLICI, J., LACK, T. (2014). Design of stanchion mechanism for secure of goods during transportation by the Shimmns wagon. In: Inovation in conception, design, production and testing of freight wagon I. November 27 - 28, 2014, Žilina, Proceedings, University of Žilina, 2014, Pp. 47-53, ISBN 978-80-554-0955-9. 
[8] KOGAN A. Ya., PEYTCHEV, Y. L. (2003). Guidelines for the calculation of non-stationary vertical stress. (In Russian). Deformed state on the path of wooden and concrete sleepers at the junction of the rails. M.: 2003, 12, 10 pages.

[9] KLIMENDA, F., SKOČILASOVÁ, B. (2015). Rollers Vibration of Pipe Convevor. In: Manufacturing Technology: journal for science, research and production. Vol. 15, No 6, Pp. 991 - 995, ISSN 1213-2489.

[10] KUDYUROV, L. V, GARIPOV, D. C. (2010). A mathematical model of a planar defect in the wheel roll surface with elastic suspension the inclusion and vertical irregularities path. (In Russian) Journal. Tech. University Press. Avg. Fyz.-math. Science. 1 (20): 178-187. UDC 517.958:625.031.1, 2010.

[11] LACK, T., GERLICI, J. (2015): The FASTSIM method modification to speed up the calculation of tangencial contact stressess between wheel and rail. In: Manufacturing Technology: journal for science, research and production. Vol. 13, No 4, Pp. 486 - 492, ISSN 1213-2489.

[12] LACK, T., GERLICI, J., MAŇUROVÁ, M. (2015a). Analysis of dynamic properties of a freight wagon II. (In Slovak) In: Innovations in conception, construction, production and testing of freight wagons II: January 29 - 30 2015, Žilina, Proceedings, University of Žilina, 2015, Pp. 51-56, ISBN 978-80-554-0980-1.

[13] LACK, T., GERLICI, J. (2015b). Computational model of the RAILBCOT test stand for the analysis of its dynamical behaviour. In: Dynamical problems in rail vehicles 2015: Polish - Slovak scientific workshop: Warsaw 2015. - Warsaw: Warsaw University of technology, 2015, Pp. 14-33, ISBN 978-83-7814-367-3.

[14] LACK, T., GERLICI, J. (2013a). Delta $r$ negative shape influence on the equivalent conicity assessment manner. In: Computational and experimental methods in applied mechanics I. Ústí nad Labem, Faculty of Production Technology and Management, UJEP, 2013, Pp. 27-36, ISBN 978-80-7414-609-1.

[15] LACK, T., GERLICI, J. (2013b). Tangential stresses evaluation over non-elliptical rail /wheel contact. In: $11^{\text {th }}$ international conference Dynamics of rigid and deformable bodies 2013, Proceedings, Ústí nad Labem, October 9 - 11 2013. - Ústí nad Labem: FVTM UJEP, 2013, CD-ROM, 9 pages, ISBN 978-80-7414-607-7.

[16] LUNYS, O., DAILYDKA, S., STEIŠŪNAS, S., BUREIKA, G. (2015). Analysis of freight wagon wheel failure detection in Lithuanian Railways. In: TRANSBALTICA 2015, the $9^{\text {th }}$ International Conference. May 7 - 8, 2015, Vilnius, Lithuania: selected papers Vilnius: Technika, 2015.

[17] MAŇUROVÁ, M., SUCHÁNEK, A. (2016). Determination of Stiffness of Triple Sprink Built in a Bogie of a Rail Vehicle. In: Manufacturing Technology: journal for science, research and production. Vol. 16, No 2, pp. 390 396, ISSN 1213-2489.

[18] MELANIN B. (2010). Strike wheels on the rail: load-deformation (In Russian). WORLD TRANSPORT 03, 2010: Pp 20-25. UDC 629.45./.46

[19] PAWELCZYK, M., PIOTR, LESIAK, PODSIADLO, R. (2015). Simulation study of the 4-axle wagon damaging impact on the track caused by some deformations of the wheel. In: $22^{\text {nd }}$ international conference „Current Problems in Rail Vehicles - PRORAIL 2015“, September 16 - 18 2015, Žilina, Slovakia, Vol. 1, Pp. 115-124, ISBN 978-80-89276-48-6.

[20] PIERINGER, A., KROPP, W., NIELSEN, J. C. O. (2014). The influence of contact modelling on simulated wheel/rail interaction due to wheel flats. Wear. 314: 273-281, 2014.

[21] POPP, K., KRUSE, H., KAISER, I. (2010). Vehicle-Track Dynamics in the Mid-Frequency Range. Vehicle System Dynamics. In: International Journal of Vehicle Mechanics and Mobility, January 2014, Pp. 37-41.

[22] SIMPACK (2014): Simpack documentation 2014, user guide (part of the program package).

[23] SKOČILASOVÁ, B., SKOČILAS, J. (2015). Nusselt number criteria equations in the cross flow over single tube. In: Manufacturing Technology, Vol. 15, No 6, Pp. 1043-1048, ISSN 1213-2489.

[24] SLADKOVSKY A., POGORELOV D. Yoo. (2008). Research study dynamic interactions in the wheel-rail contact in the presence of slides on the wheel pair. (In Russian) Bichik No. 5 (123), 2008: c. 88-95. UDC 629.4.004: 531.39.

[25] SMETANKA, L., GERLICI, J., LACK, T., PELAGIĆ, Z. (2015): In: Manufacturing Technology: journal for science, research and production. Vol. 15, No 5, pp. 914 - 920, ISSN 1213-2489.

[26] SOUKUP, J., ŽMINDÁK, M., SKOČILAS, J., RYCHLÍKOVÁ, L. (2014). Application of mesh-free methods in transient dynamic analysis of orthotropic plates. In: Manufacturing Technology: journal for science, research and production. Vol. 14, No 3, Pp. 441-4470, ISSN 1213-2489. 
[27] SUCHÁNEK, A., MAŇUROVÁ, M. (2015). Determination of anti-roll bar stiffness of a bogie for a rail vehicle with a tilting body. In: Dynamics of rigid and deformable bodies 2015, $13^{\text {th }}$ International Scientific Conference Ústí nad Labem, Czech Republic, October 7 - 9, 2015, Proceedings, Ústí nad Labem: FVTM UJEP, 2015, CDROM, 8 pages, ISBN 978-80-7414-914-6.

[28] SUCHÁNEK, A., HARUŠINEC, J. (2015). The downhill braked railway wheel structural analysis by means of the ANSYS Multiphysics program system package. In: Manufacturing Technology: journal for science, research and production. Vol. 15, No 5, 2015, Pp. 945-950, ISSN 1213-2489.

[29] SVOBODA, M., SOUKUP, J., JELEN, K., KUBOVÝ, P. (2015). Effects of impacts on human head. In: Manufacturing Technology: journal for science, research and production. Vol. 15, No 2, Pp. 336-231, ISSN $1213-2489$.

[30] SVOBODA, M., SOUKUP, J. (2013). Verification of numeric solution by experiment for examination vertical oscillation of a mechanical system. In: Manufacturing technology: journal for science, research and production. Vol. 13, No. 4, 2013, Pp. 559-563, ISSN 1213-2489.

[31] ŠŤASTNIAK, P. (2015a). Freight long wagon dymamic analysis in S-curve by means of computer simulation. In: Manufacturing technology: journal for science, research and production. Vol. 15, No. 5, 2015, Pp. 930-935, ISSN 1213-2489.

[32] ŠŤASTNIAK, P. (2015b). Wagon chassis frame design with adaptable loading platform. In: Manufacturing Technology: journal for science, research and production. Vol. 15, No. 5, 2015, Pp. 935-940, ISSN 1213-2489.

[33] WALLENTIN, M. BJARNEHED, H. L., LUNDÉN, R. (2005). Cracks around railway wheel flats exposed to rolling contact loads and residual stresses. Wear. 258: 1319-1329, 2005. 